KEMAS 9 (1) (2013) 153-159
Jurnal Kesehatan Masyarakat

\title{
EFEKTIVITAS PROGRAM P4GN TERHADAP PENCEGAHAN PENYALAHGUNAAN NAPZA
}

Qomariyatus Sholihah ${ }^{\bowtie}$

Program Studi Kesehatan Masyarakat Fakultas Kedokteran Universitas Lambung Mangkurat

\section{Info Artikel}

Sejarah Artikel:

Diterima 2 September 2014

Disetujui 14 Oktober 2014

Dipublikasikan Januari 2015

Keywords:

P4GN;

Drugs;

Counseling;

\begin{abstract}
$\underline{\text { Abstrak }}$
NAPZA adalah singkatan dari narkotika, psikotropika, dan zat adiktif. Penyalahgunaan NAPZA tidak saja berbahaya dan merugikan keluarga, tetapi menimbulkan dampak soasial yang luas. Program Pencegahan, Pemberantasan Penyalahgunaan dan Peredaran Gelap Narkoba (P4GN) perlu dilakukan dengan berfokus pada kegiatan pencegahan sebagai upaya menjadikan para tenaga kerja memiliki pola pikir, sikap, dan terampil menolak penyalahgunaan dan peredaran gelap narkoba. Penelitian ini diharapkan dapat menggambarkan efektivitas penyuluhan program P4GN terhadap pencegahan penya lahgunaan NAPZA pada pekerja. Penelitian pada tahun 2014 dan dilaksanakan pada 50 orang tenaga kerja bongkar muat di Pelabuhan Trisakti Banjarmasin. Instrumen penelitian menggunakan kuesioner dan media penyuluhan. Sebelum dilaksanakan penyuluhan diberikan pre test dan post test setelah penyuluhan untuk menilai efektifitas penyuluhan P4GN. Hasil analisis dengan uji Wilcoxon menunjukkan bahwa ada terdapat perbedaan pengetahuan yang bermakna antara sebelum penyuluhan dengan sesudah dilakukan penyuluhan. Penelitian ini diharapkan dapat meningkatkan pengetahuan tenaga kerja terhadap NAPZA sehingga dapat menghindari penyalahgunaan NAPZA.
\end{abstract}

\section{EFFECTIVENESS P4GN PROGRAM FOR DRUG ABUSE PREVENTION}

\begin{abstract}
Drug stands for narcotics, psychotropic, and addictive substances. Drug abuse is not only dangerous and detrimental to the family, but soasial broad impact. Prevention, Combating Abuses and Illicit Drugs (P4GN) program needed to focusing on prevention activities in an effort to make the workforce have the mindset, attitudes, and skilled refusing abuse and illicit drug trafficking. This research is expected to describe the effectiveness of counseling programs P4GN on the prevention of drug abuse workers. The research was conducted in 2014 on 50 workers unloading at the Port of Trisakti Banjarmasin. The research instrument used questionnaires and education media. Before implementation is given pre-test counseling and post-test after counseling to assess the effectiveness of counseling P4GN. The results of the analysis with the Wilcoxon test showed that there were significant differences between the knowledge before and after of the counseling. This research is expected to increase the knowledge workers of the drug so as to avoid drug abuse.
\end{abstract}

(C) 2015 Universitas Negeri Semarang

\footnotetext{
Alamat korespondensi:

Program Studi Kesehatan Masyarakat Fakultas Kedokteran Universitas Lambung

Mangkurat, Banjarbaru, Indonesia

E-mail: qoqom_kuncoro@yahoo.co.nz
} 


\section{Pendahuluan}

NAPZA adalah kepanjangan dari narkotika, psikotropika, dan bahan adiktif lainnya yang merupakan sekelompok obat, yang berpengaruh pada kerja tubuh, terutama otak. Satu sisi narkoba merupakan obat atau bahan yang bermanfaat di bidang pengobatan, pelayanan kesehatan, dan pengembangan ilmu pengetahuan. Namun, di sisi lain dapat menimbulkan ketergantungan apabila dipergunakan tanpa adanya pengendalian.

NAPZA (Narkotika, Psikotropika, dan Zat Adiktif lain) adalah bahan/ zat/ obat yang bila masuk ke dalam tubuh manusia akan mempengaruhi tubuh terutama otak/ susunan saraf pusat, sehingga menyebabkan gangguan kesehatan fisik, psikis, dan fungsi sosialnya karena terjadi kebiasaan, ketagihan (adiksi) serta ketergantungan (dependensi) terhadap NAPZA. Penyalahgunaan NAPZA adalah penggunaan salah satu atau beberapa jenis NAPZA secara berkala atau teratur diluar indikasi medis, sehingga menimbulkan gangguan kesehatan fisik, psikis dan gangguan fungsi sosial (Azmiyati, 2014).

Penyalahgunaan NAPZA di dunia terus mengalami kenaikan dimana hampir 12\% (15,5 juta jiwa sampai dengan 36,6 juta jiwa) dari pengguna adalah pecandu berat. Menurut World Drug Report tahun 2012, produksi NAPZA meningkat salah satunya diperkiraan produksi opium meningkat dari 4.700 ton di tahun 2010 menjadi 7.000 ton di tahun 2011 dan menurut penelitian yang sama dari sisi jenis narkotika, ganja menduduki peringkat pertama yang disalahgunakan di tingkat global dengan angka pravalensi 2,3\% dan 2,9\% per tahun (Andriyani, 2011).

Kasus penyalahgunaan NAPZA di Indonesia dari tahun ke tahun juga terus mengalami kenaikan dimana pada tahun 2008 ada sebanyak 3.3 juta (3.362.527) dengan pravalensi $1,99 \%$ menjadi pada tahun 2011 menjadi 4 juta (4.071.016) dengan pravalensi $2,32 \%$ dan diprediksikan angka tersebut akan terus mengalami kenaikan pada tahun 2015 menjadi 5,1 juta (5.126.913) dengan pravalensi 2,8\%. Diketahui 5,3\% di antaranya adalah kalangan pelajar dan mahasiswa.

Kalimantan Selatan berdasarkan kasus narkoba yaitu menempati peringkat ke 6 pada tahun 2012 dengan jumlah kasus 1.188 yang awalnya peringkat ke 9 pada tahun 2011 dengan jumlah kasus 887. Ibukota Kalimantan Selatan yaitu Banjarmasin menempati peringkat pertama dari 12 kabupaten yang ada. Hal tersebut dilihat dari rekapitulasi data narkoba BNNP kalsel dan jajaran polda kalsel tahun 2012 dan masih bertahan sampai tahun 2013 (BNNP dan Polda Kalsel, 2013).

Ketergantungan zat merupakan dampak dari penyalahgunaan NAPZA yang parah, hal ini sering dianggap sebagai penyakit. Ketergantungan seperti ketidakmampuan untuk mengendalikan atau menghentikan pemakaian zat menimbulkan gangguan fisik yang hebat jika dihentikan akan berbahaya dan merugikan keluarga serta menimbulkan dampak sosial yang luas. Salah satu faktor yang berpengaruh terhadap penyalahgunaan NAPZA adalah pengetahuan, dimana dalam suatu kondisi jika seseorang itu tahu bahwa hal yang akan dilakukannya akan berakibat buruk terhadap dirinya maka orang tersebut kemungkinan tidak akan melakukan hal tersebut (Menthan, 2013). Peningkatan pengetahuan dapat dilakukan dengan cara penyuluhan. Hal ini sejalan dengan penelitian yang menyatakan bahwa ada peningkatan pengetahuan yang signifikan setelah pemberian penyuluhan (Badri M, 2013).

Program Pencegahan, Pemberantasan Penyalahgunaan dan Peredaran Gelap Narkoba (P4GN) merupakan program yang dicanangkan oleh pemerintah melalui BNN tahap tahun 2011-2015 dengan tujuan mengendalikan penyalahgunaan NAPZA. P4GN ini dilaksanakan untuk menjadikan 97,2\% penduduk Indonesia imun terhadap penyalahgunaan dan peredaran gelap narkoba dan $2,8 \%$ penduduk Indonesia (penyalahguna narkoba) secara bertahap mendapat layanan rehabilitasi medis dan rehabilitasi sosial).

Berdasarkan instruksi preasiden tahun 2011, salah satu fokus program P4GN adalah upaya pengawasan ketat terhadap inpor, produksi, distribusi, penggunaan (end user), ekspor, dan re-ekspor bahan kimia prekusor dan penegakan hukum terhadap jaringan tersangka yang melakukan penyimpangan. Pekerjaan yang berhubungan dengan 
pengawasan tersebut adalah pekerja bongkar muat di pelabuhan Trisakti Banjarmasin.

NAPZA adalah singkatan dari narkotika, psikotropika, dan zat adiktif. Narkotika disebut juga sebagai obat-obatan anastesi, penggunaan narkotika dapat mengakibatkan kehilangan kesadaran karena pengaruh sistem susunan saraf pusat. Narkotika merupakan obat yang berasal dari tanaman yang dapat menyebabkan hilang kesadaran dan dapat menimbulkan ketergantungan. Golongan I adalah narkotika yang hanya dapat digunakan untuk tujuan ilmu pengetahuan dan tidak ditujukan untuk terapi serta mempunyai potensi sangat tinggi menimbulkan ketergantungan, contohnya heroin. Narkotika golongan II adalah narkotika yang memiliki khasiat pengobatan dan sering digunakan sebagai obat alternatif tapi sebagai pilihan yang terakhir, contohnya morfin. Berdasarkan Undang-Undang No.5 Tahun 1997, psikotropika adalah zat atau obat, baik alamiah maupun sintetis bukan narkotika, yang berkhasiat psikoaktif melalui pengaruh selektif pada susunan saraf pusat yang menyebabkan perubahan khas pada aktivitas mental dan perilaku. Zat adiktif adalah bahan yang dapat menimbulkan kerugian bagi seseorang yang menggunakannya akibat timbulnya ketergantungan psikis seperti golongan alkohol, nikotin dan sebagainya. Jenis-jenis NAPZA antara lain heroin, morfin, ganja, ekstasi, sabusabu, obat penenang, dan alkohol.

Penyalahgunaan NAPZA sangat memberikan efek yang tidak baik dimana bias mengakibatkan adiksi (ketagihan) yang berakibat pada ketergantungan. Menurut Hawari, hal tersebut terjadi karena sifat-sifat narkoba yang menyebabkan (Azmiyati, SR, 2014):

1) Keinginan yang tidak tertahankan (an over powering desire) terhadap zat yang dimaksud dan kalau perlu dengan jalan apapun untuk memperolehnya.

2) Kecendrungan untuk menambahkan takaran atau dosis dengan toleransi tubuh.

3) Ketergantungan psikologis, yaitu apabila pemakaian zat dihentikan akan menimbulkan gejala-gejala kejiwaan, seperti kegelisahan, kecemasan, depresi, dan sejenisnya.

4) Ketergantungan fisik yaitu apabila pemakaian zat dihentikan akan menimbulkan gejala fisik yang dinamakan gejala putus obat (withdrawal symptoms).

Penyalahgunaan NAPZA biasa didasari atas beberapa hal yang menyebabkan seseorang menjadi penyalahguna NAPZA. Pada dasarnya dapat dikelompokkan menjadi dua bagian besar. Pertama, sebab-sebab yang berasal dari faktor individu seperti pengetahuan, sikap, kepribadian, jeins kelamin, usia, dorongan kenikmatan, perasaan ingin tahu, dan untuk memecahkan persoalan yang sedang dihadapi. Kelompok kedua berasal dari lingkungannya seperti pekerjaan, ketidakharmonisan keluarga, kelas sosial ekonomi, dan tekanan kelompok (Badri M, 2013).

P4GN merupakan program yang dicanangkan oleh pemerintah melalui BNN tahap tahun 2011-2015. Tujuan utama program P4GN adalah pemberdayaan segenap potensi yang ada di seluruh lapisan masyarakat agar secara sadar melakukan gerakan untuk menentang/menolak penyalahgunaan dan peredaran gelap narkoba. Program P4GN tidak hanya bersifat pencegahan bahaya penyalahgunaan narkoba, akan tetapi meliputi kegiatan penegakkan hukum bagi penyalahguna narkoba dan kegiatan rehabilitasi bagi korban penyalahgunaan narkoba.

Penyuluhan NAPZA adalah semua upaya secara sadar dan berencana yang dilakukan untuk memperbaiki perilaku manusia, sesuai prinsip-prinsip pendidikan, yakni pada tingkat sebelum seseorang menggunakan NAPZA, agar mampu mengghindari dari penyalahgunaan. Sasaran dari upaya ini adalah orang-orang dengan risiko tinggi yang memiliki masalah yang tidak mampu dipecahkan sendiri, sehingga dalam kehidupannya sering mencari pemecahan keliru, seperti perilaku untuk kepuasan sementara melalui penggunaan NAPZA (Badri M, 2013).

Penyalahgunaan zat tidak saja berbahaya dan merugikan keluarga dan menimbulkan dampak soasial yang luas, sehingga P4GN perlu dilakukan dalam dengan berfokus pada kegiatan pencegahan sebagai upaya menjadikan para pekerja memiliki pola pikir, sikap, dan terampil menolak penyalahgunaan dan peredaran gelap narkoba. Penelitian ini diharapkan dapat menggambarkan efektivitas penyuluhan program P4GN terhadap 
pencegahan penyalahgunaan NAPZA pada pekerja.

\section{Metode}

Penelitian ini merupakan penelitian observasional analitik dengan menggunakan pendekatan cross sectional karena data yang diperoleh melalui pengamatan, tanpa adanya perlakuan dalam waktu sesaat dengan tujuan untuk membandingkan perbedaan pengetahuan sebelum dan sesudah penyuluhan P4GN dilakukan.

Populasi penelitian ini pekerja bongkar muat di pelabuhan Trisakti Banjarmasin yang berjumlah 831 orang dan dibagi menjadi 16 kelompok atau group dimana 1 kelompok atau group berjumlah rata-rata 50 orang. Sampel yang selanjutnya disebut responden pada penelitian ini adalah satu kelompok atau group yang berjumlah 50 orang yang bekerja saat penyuluhan berlangsung dengan menggunakan totaly sampling atau diambil seluruh pekerja yang bekerja saat itu.

Instrumen penelitian menggunakan kuesioner dan media penyuluhan. Variabel bebas pada penelitian ini adalah penyuluhan P4GN dan variabel terikat adalah pengetahuan tentang program P4GN. Data primer pada penelitian ini adalah data yang dikumpulkan langsung berupa data dari pre-test dan posttest tentang pengetahuan pekerja mengenai P4GN. Data sekunder yang digunakan pada penelitian adalah data jumlah pekerja bongkar muat di pelabuhan Trisakti Banjarmasin. Teknik analisis data pada penelitian ini dengan uji $t$-test berpasangan. Uji ini digunakan untuk mengetahui efektivitas dari penyuluhan P4GN yang dilakukan sebagai upaya peningkatan pengetahuan mengenai P4GN.

\section{Hasil dan Pembahasan}

Penyuluhan ini dilaksanakan di Pelabuhan Trisakti (PT. Pelabuhan Indonesia III Cabang Banjarmasin) dengan jumlah karyawan pekerja bongkar muat di pelabuhan Trisakti Banjarmasin yang diberi penyuluhan yaitu 50 orang. Penyuluhan dilaksanakan dengan cara memberikan pre test dan post test kepada obyek penyuluhan.
Untuk mengetahui tingkat keberhasilan punyuluhan ini maka dilakukan pre test dan post test, hasil dari penyuluhan didapatkan bahwa terjadi peningkatan pengetahuan responden. Rata-rata terjadi peningkatan pengetahuan pada responden sebesar 30\%. Peningkatan pengetahuan yang terjadi pada responden meliputi pengertian dari NAPZA, kandungankandungan yang terdapat dalam NAPZA dan dampak yang terjadi jika melakukan penyalahgunaan napza.

Untuk mengetahui tingkat keberhasilan punyuluhan ini maka dilakukan uji statistik lebih lanjut.

Hasil uji Wilcoxon, dengan uji tersebut diperoleh nilai significancy 0,0001 $(\mathrm{p}<0,05)$, dengan demikian dapat disimpulkan "terdapat perbedaan pengetahuan yang bermakna antara sebelum penyuluhan dengan sesudah dilakukan penyuluhan".

Kegiatan pengabdian kepada masyarakat tentang "Upaya Penyelamatan Generasi Muda Melalui Penyuluhan Pengetahuan Bahaya dan Cara Penanggulangan Penyalahgunaan Narkoba" di Kabupaten Kulon Progo berhasil memberikan bekal tentang bahaya Narkoba bagi kesehatan dan masa depan siswa SMP dan SMA di Kabupaten Kulon Progo dan memberikan pemahaman pentingnya kesadaran mereka dalam melakukan pencegahan diri terhadap pengaruh narkoba yang dapat datang dari teman bergaul di sekolah dan di rumah, lingkungan masyarakat sekitar, dan media massa yang dapat menghancurkan masa depannya. Kegiatan ini sangat menarik dan tepat sasaran, hal ini tercermin dari antusiasme mereka dalam mengikuti penyuluhan dan mengajukan pertanyaan tentang banyak hal dalam forum diskusi (tanya jawab).

Kegiatan penyuluhan merupakan suatu proses komunikasi dua arah, ada komunikator dan komunikan yang selalu berhubungan dalam suatu interaksi. Di satu pihak komunikator (penyuluh) beusaha mempengaruhi komunikan agar terjadi perubahan pengetahuan dari tidak tahu menjadi tahu dan dari tidak mengerti menjadi mengerti serta diharapkan terjadi perubahan tindakan dan perilaku. Komunikasi dan penyuluhan sangat di tentukan oleh bentuk hubungan antar penyuluh selaku komunikator dengan sasaran yaitu remaja atau masyarakat 
selaku komunikan. Jika diantara kedua belah pihak telah terjadi penyesuaian, komunikasi akan berjalan lancar (Kaddi SM, 2014).

Penyalahgunaan narkotika, psikotropika, dan zat adiktif (NAPZA) merupakan suatu ancaman dan permasalahan yang komplek yang dapat menghancurkan generasi muda. Sampai saat ini belum semua masyarakat sadar dan tahu tentang bahaya penyalahgunaan NAPZA. Penyalahgunaan NAPZA bisa mengakibatkan kecanduan dan mengakibatkan ganguan secara klinis atau fungsi sosial. Oleh karena itu, perlunya penyuluhan untuk menambah pengetahuan seputar NAPZA (Ricardo, 2010).

Persoalan narkoba merupakan persoalan yang harus ditangani secara sungguh-sungguh oleh seluruh komponen masyarakat. Bukan saja penanganan bagi penggunanya, melainkan juga perkembangan bisnis narkoba yang ada di Indonesia sudah mulai menggelisahkan. Bagaimana pemerintah dan aparat penegak hukum melalui BNN juga memberantas pengedar dan produsennya. Kita tidak ingin di kemudian hari negara kita dikuasai oleh kartel-kartel narkoba seperti yang terjadi di negara Amerika Latin. Advokasi dan KIE juga merupakan bentuk komunikasi yang dilaksanakan sebagai salah satu bentuk program pencegahan. Advokasi merupakan bentuk rangkaian komunikasi strategis yang dirancang secara sistematis dan dilaksanakan dalam kurun waktu tertentu, baik oleh individu maupun kelompok masayarakat.

Narkoba seringkali disalahgunakan oleh banyak kalangan masyarakat. Ketergantungan pengguna narkoba ini sulit untuk disembuhkan, tidak hanya karena zat nikotin yang terkandung di dalamnya tetapi juga lingkungan yang tidak sehat dan keinginan pengguna narkoba itu sendiri. Rehabilitasi narkoba menjadi sebuah wadah untuk memberikan pertolongan agar pengguna narkoba dapat sembuh. Namun, banyak rehabilitasi narkoba di Indonesia yang belum memperhatikan lingkungan sebagai faktor penting dalam proses penyembuhan (Sinaga VM, 2011).

Tingginya angka penyalahgunaan narkoba tersebut juga disumbang oleh ulah pada sindikat narkoba. Kepolisian Republik Indonesia (Polri) sebagai garda depan dalam perang melawan narkoba di Indonesia terus membuktikan kemampuannya untuk memenangi perang tersebut. Sepanjang tahun 2008, polisi berusaha menunjukkan prestasi melaluiberbagaitindakan pengungkapankasuskasus penyalahgunaan serta pembongkaran jaringan perdagangan narkoba (Ricardo, 2010).

Peredaran narkoba yang dilakukan dengan teknik canggih telah merambah seluruh Indonesia. Dapat dikatakan terjadi perubahan modus dari para sindikat, dimana khusus jenis psikotropika tidak lagi diimpor namun pengedarnya lebih memilih membuat pabrik untuk memproduksi sendiri. Pengadaan bahan baku, peracikan, hingga perekrutan orang terkait pembagian tugas dalam memproduksi narkoba benar-benar direncanakan dengan baik. Hal ini dapat dikatakan ketika melihat tren kasus pabrik-pabrik narkoba yang terus bermunculan (Ricardo, 2010).

Peran penting pihak kepolisian dalam tugasnya memberantas kasus kejahatan terkait narkoba harus didukung dengan baik,walaupun angka-angka kasus tersebut tetap meningkat. Terungkapnya kasus-kasus di satu sisi memang dapat menjadi indikator meningkatnya kerja polisi dalam memburu sindikat peredaran narkoba, namun di sisi lain dapat memberi petunjuk betapa kebijakan pemerintah saat ini lemah dalam menghadapi peredaran tersebut (Ricardo, 2010).

Penyalahgunaan NAPZA sangat memberikan efek tidak baik dimana bisa mengakibatkan adiksi yang berujung pada ketergantungan. Setelah ketergantungan terjadi, maka hasrat akan menggunakannya lagi tak akan bisa tertahankan yang berakibat menimbulkan gangguan psikologis dan ketergantungan fisik dimana jika pemakaian NAPZA dihentikan akan menimbulkan perasaan gelisah, cemas, depresi, dan lain-lain.

Pengetahuan merupakan faktor penyalahgunaan NAPZA, dimana pengetahuan akan mempengaruhi tindakan apa yang akan dia ambil. Dalam penelitian yang dilakukan Wishesa didapatkan hasil bahwa terdapat hubungan yang signifikan antara tingkat pengetahuan dengan penyalahgunaan narkoba. Selain itu sosialisasi tentang penyalahgunaan narkoba yang masih kurang kurang selama ini juga disebabkan adanya keterbatasan tenaga penyuluh dan sumber-sumber pendukung 
lainnya berupa sarana dan prasarana seperti ketersediaan buku-buku tentang bahaya narkoba maupun video-video tentang bahaya penyalahgunaan narkoba serta media elektronik lainnya, sehingga berdampak dari kurang optimalnya pelaksanaan program pencegahan penyalahgunaan narkoba (Udana M, 2013).

Pengetahuan merupakan aspek kognitif yang diidentifikasi berperan penting dalam penyalahgunaan NAPZA adalah rendahnya pengetahuan tentang NAPZA. Strategi prevensi penyalahgunaan NAPZA dilakukan dengan pendekatan kognitif behavioral, yaitu dengan memberikan program yang berisi pengetahuan tentang NAPZA serta mengajarkan dan melatihkan keterampilan sosial yang berhubungan dengan kemampuan untuk menolak bujukan penyalahguna NAPZA (Afiatin T, 2004).

Di Indonesia, program pencegahan penyalahgunaan NAPZA pada remaja telah dilakukan dengan aktivitas yang bertujuan untuk meningkatkan pengetahuan anggota masyarakat tentang penggunaan dan penyalahgunaan obat. Kegiatan dilakukan dengan memberikan penyuluhan melalui ceramah, pemutaran film, dan diskusi tentang penyalahgunaan NAPZA khususnya bagi generasi muda (Afiatin T, 2004).

Soeweno menyatakan bahwa sesungguhnya aktivitas tersebut belum cukup memadai untuk pencegahan penyalahgunaan NAPZA di kalangan generasi muda, sehingga perlu direncanakan aktivitas lain berkaitan dengan program pengembangan ketrampilan personal dan interpersonal pada generasi muda. Mereka perlu diberikan ketrampilan komunikasi, pengambilan keputusan, dan peningkatan harga diri sebagai upaya peningkatan kompetensi pribadi dan sosial. Program prevensi penyalahgunaan NAPZA pada remaja harus meliputi pemberian informasi atau pengetahuan yang tepat tentang NAPZA, serta memberikan ketrampilan sosial bagi remaja untuk meningkatkan kompetensi personal dan sosialnya (Afiatin T, 2004).

Adapun pengetahuan yang harus dimiliki seseorang untuk menghindari penyalahgunaan NAPZA adalah tingkat ketepatan subjek merespon informasi yang membahas pengertian tentang narkotika, psikotropika, dan zat adiktif lainnya, penyalahgunaan NAPZA, bahaya penyalahgunaan NAPZA, cara-cara penyebaran dan penghindaran penyalahgunaan NAPZA. Dengan pengetahuan tentang NAPZA yang cukup masyarakat dapat berargumentasi untuk dapat menghindari diri dar penyalahgunaan NAPZA (Afiatin T, 2004).

Program P4GN bidang pencegahan mempunyai tugas melaksanakan kebijakan teknis P4GN di bidang pencegahan dalam wilayah kerja dengan fungsi pelaksanaan desiminasi informasi P4GN di bidang pencegahan, pelaksanaan advokasi P4GN di bidang pencegahan dan pelaksanaan bimbingan teknis P4GN di bidang pencegahan dengan arah kegiatan yaitu mendekatkan layanan informasi program $\mathrm{P} 4 \mathrm{GN}$ bidang pencegahan kepada masyarakat dengan melakukan tugas seperti wahana diseminasi, sosialisasi dan pembentukan kader.

Rendahnya tingkat pendidikan masyarakat mempengaruhi pengetahuan masyarakat tentang NAPZA, hal ini terlihat dari hasil post-test yang diberikan sangat baik dibandingkan dengan pre-test. Selain itu juga dikarenakan tidak efektifnya program pemantauan resep obat serta kurangnya dana program monitoring NASPER (National All Schedules Prescription Electronic Reporting), dan pendekatan reaktif oleh lembaga. Sejalan dengan penelitian yang dilakukan oleh Givaudan, bahwa untuk melakukan pencegahan penyalahgunaan dan peredaran gelap narkoba di Mexico, maka dilakukan melalui program "Yo quero, yo puedo" (Saya ingin, Saya bisa). Dengan dukungan Mentor Faundation, untuk melakukan penyuluhan, komunikasi, negoisasi, dan pemecahan masalah untuk meningkatkan pengetahuan masyarakat sehingga memungkinkan semua kalangan baik anak-anak, guru dan orang tua untuk menolak penggunaan narkoba. Intervensi integral melalui jaringan dukungan dari sekolah, rumah dan masyarakat tentang pencegahan penyalahgunaan narkotika (Hery, 2008).

\section{Penutup}

Berdasarkan hasil penelitian menggunakan uji Wilcoxon dengan nilai 
significancy 0,000 $(\mathrm{p}<0,05)$ terdapat perbedaan pengetahuan yang bermakna antara sebelum penyuluhan dengan sesudah dilakukan penyuluhan.

\section{Ucapan Terima Kasih}

Dalam kegiatan penelitian ini peneliti mengucapkan terima kasih kepada pertama koperasi pekerja bongkar muat di pelabuhan Trisakti Banjarmasin telah memberikan izin kepada peneliti untuk melakukan penelitian, kedua kepada seluruh pekerja yang telah membantu dan bekerja sama dengan baik selama kegiatan penelitian khusunya pekerja bongkar muat, ketiga kepada BNNP kalsel dan jajaran polda kalsel yang telah membantu memberikan data studi pendahuluan.

\section{Daftar Pustaka}

Afiatin T. 2004. Pengaruh Program Kelompok "Aji" Dalam Peningkatan Harga Diri, Assertivitas, dan Pengetauan Mengenai Napza untuk Prevensi Penyalahgunaan Napza pada Remaja. Jurnal Psikologi, 1: 28-54.

Andriyani, T. 2011. Upaya Pencegahan Tindak Penyalahgunaan Narkoba di Kalangan Mahasiswa Politeknik Negeri Sriwijaya. Jurnal Ilmiah Orasi Bisnis, (4) : 113-121.

Azmiyati, SR, dkk. 2014. Gambaran penggunaan NAPZA pada anak jalanan di Kota Semarang.
Jurnal Kesehatan Masyarakat (KEMAS), 9 (2): 137-143.

Badri M. Implementasi Undang-Undang No. 35 Tahun 2009 Tentang Narkotika Dalam Pelaksanaan Wajib Lapor Bagi Pecandu Narkotika. Jurnal Ilmiah Universitas Batanghari Jambi, 13 (3): 7-12.

BNNP dan Polda Kalsel. 2013. Data Rekapitulasi Data Narkoba.

Kaddi SM. Strategi Penyuluhan Kesehatan Masyarakat Dalam Menanggulangi Bahaya Narkoba di Kabupaten Bone. Jurnal Academica Fisip Untad, 6 (1): 1178-1185.

Menthan, Fadrian. 2013. Peranan Badan Narkotika Nasional Kota Samarinda dalam Penanggulangan Masalah Narkoba di Kalangan Remaja Kota Samarinda. Ejournal Administrasi Negara, 1 (2): 544-557.

Ricardo P. 2010. Upaya Penaggulangan Penyalahgunaan Narkoba Oleh Kepolisian (Studi Kasus Satuan Narkoba Polres Metro Bekasi). Jurnal Kriminologi Indonesia, 6 (3) : 232-245.

Sinaga VM dan Wardono P. Citespong House OF Drug Rehabilitation Center 2011. Program Studi Sajana Desain Interior Fakultas Seni Rupa dan Desain Institut Teknologi Bandung. Jurnal Tingkat Sarjana Senirupa dan Desain: 1-6.

Udana M. 2013. Implementasi Program Pencegahan Penyalahgunaan Narkoba Oleh BNN Kota Pontianak pada Siswa SMAN 2 Kota Pontianak. Jurnal S1 Ilmu Administrasi Negara 2 (2): 1-9. 